\title{
Reading and Resisting the Representations of Black Africans in Joseph Conrad's Heart of Darkness
}

\author{
Victoria Cowan*
}

\begin{abstract}
This article adapts feminist critic Judith Fetterley's articulation of resistant reading to the colonial context in order to perform a racially ethical reading of Joseph Conrad's Heart of Darkness. Adapting a feminist practice of resistant reading to the colonial context is possible because of the ways in which the structures of patriarchal and colonialist discourses are homologous. This article approaches Conrad's text as a piece of colonialist discourse by tracing the ways in the Congolese people are represented as wild, dark, animalistic, and incomplete. Employing this methodology is useful, indeed arguably essential, for reading Conrad's representations of black Africans in his novella because doing so hinders the perpetuation of a debilitating, dehumanizing discourse "in which the very humanity of black people is called into question" (Achebe 346).
\end{abstract}

Keywords: representation, black Africans, Conrad, Joseph, Heart of Darkness, colonialist discourse, resistant reading

Joseph Conrad's Heart of Darkness has been lauded as a stylistic achievement of European literature since its publication in 1899. Critic Chinua Achebe describes Conrad's novella as "permanent literature ... read and taught and constantly evaluated by serious academics" (337), an attestation to its prominence in the Western literary canon and psyche. Also widely disputed is whether Conrad's novella is anti-imperialist or imperialist in its attitudes and assumptions. The text is, in fact, both. Many elements within Heart of Darkness align with Conrad's liberal anti-imperialist leanings, such as the ways in which the text illustrates colonialism's contingencies and permits its readers to imagine an Africa that has not been ravaged by the European scramble (Said 25-6). Alongside these features of the novella, however, many other elements exist that more readily align themselves with colonialist discourses of alterity and barbarity, particularly its representations of black African characters. The fact that the text embodies both discourses makes it difficult to decide whether or not reading the text is worth the risk of perpetuating its more reprehensible elements. Indeed, reading any text entails the risk of absorbing, to varying degrees, the text's politics and assumptions and of reproducing its structures of power within oneself and within the larger social sphere. Thus, such texts require certain preparations prior to reading. In the feminist context, critic Judith Fetterley has articulated a methodology of "resistant reading" in order to defend against the rhetorical and literal attacks she sees patriarchal discourse waging in many works of "classic" American literature. Resistant reading achieves its aims by making a text's political-in this case, patriarchal-schema discernible and, in that way, open to change. Because the structures of patriarchal and colonialist discourses are homologous, a practice of resistant reading can be adapted to the colonial context. Employing this methodology in the colonial context is essential for reading Conrad's representations of black Africans in Heart of Darkness. Embracing Fetterley's methodology to read Conrad's work hinders the perpetuation of a debilitating, dehumanizing

*Department of English, College of Arts and Science, University of Saskatchewan, Saskatoon, SK, Canada

Correspondence: vicj.cowan@gmail.com

University of Saskatchewan Undergraduate Research Journal Volume 1, Issue 1, 2014, 27-31 
discourse "in which the very humanity of black people is called in question" (Achebe 346).

Fetterley's articulation of resistant reading centres on the confusion of consciousness that she argues afflicts the female reader when she reads literature embedded within a patriarchal schema: "In such fictions the female reader is co-opted into participation in an experience from which she is explicitly excluded; she is asked to identify with a selfhood that defines itself in opposition to her; she is required to identify against herself" (xii; emphasis added). This identification against self in the female reader's experience of reading results in her continued disempowerment and dehumanization. Powerlessness characterizes both the experience and the content of what is being read (xiii); "the dominion of personhood [is] lost" as the female reader "undergoes a transformation into an 'it"" (ix). The female reader is further isolated from herself as she is forced to "dissociate... from the very experience the literature engenders" (xiii). Adrienne Rich echoes this notion when she states that the female reader "goes to poetry or fiction looking for her way of being in the world and over and over again she comes up against something that negates everything she is about" (21). This experience, as Fetterley notes, can ultimately force the female reader into self-hatred, self-doubt, and estrangement from her own experience (xxi). Such literature, then, is rhetorically and literally harmful to the female reader and must be read with varying degrees of resistance.

Alongside a confused consciousness, Fetterley states that it is also the obfuscation of what causes this confusion that keeps the female reader disempowered and dehumanized. It is from this obfuscation that Fetterley begins her articulation of resistant reading: "One of the main things that keeps the design of our literature unavailable to the consciousness of the woman reader, and hence impalpable, is the very posture of the apolitical, the pretense that literature speaks universal truths" (xi). If the posture of such literature is apolitical, then the methodology of resistant reading is utterly political. First and foremost, this methodology aims to clarify what has been obscured and reveal what has been concealed so as to put the politics and power of the literature in question under the lens of a new, critical consciousness. Resistant reading engages and changes consciousness just as the act of reading does. As Fetterley states, "Consciousness is power" (xix), and it is consciousness, both in the sense of personhood and of awareness, that is resistant reading's central concern and primary source of power.

Another primary aim of resistant reading is, thus, to change the consciousness of the female reader from confused to clarified and, in turn, to do the same with the consciousness of the larger culture (viii). Rich notes that "A change in the concept of sexual identity is essential if we are not going to see the old political order re-assert itself in every new revolution. We need to know the writing of the past, and know it differently than we have ever known it; not to pass on a tradition but to break its hold over us" (1819). Resistant reading is a preparation that allows one to resist rather than assent to the politics and assumptions of a text. Further, this practice allows one to prevent oneself from reproducing a text's destructive discourse both in self and in society.

Fetterley's understanding of confused consciousness in the feminist context is paralleled in the following statement made by Bill Ashcroft, Gareth Griffiths, and Helen Tiffin about discourse in the colonial context:

Although it is generated within the society and cultures of the colonizers, it becomes that within which the colonized may also come to see themselves. At the very least, it creates a deep conflict in the consciousness of the colonized because of its clash with other knowledges (and kinds of knowledge) about the world. (35; emphasis added)

In speaking of Edward Said's Orientalism, Ania Loomba echoes the sense of obfuscation that Fetterley articulates: "'knowledge' about non-Europeans was part of the process of maintaining power over them; thus the status of 'knowledge' is demystified, and the lines between the ideological and the objective blurred" (44-5i emphasis added). Both discourses reveal the ways in which power is gained, maintained, and disguised. Furthermore, Loomba's articulation of discourse analysis parallels that of resistant reading: "Discourse analysis ... makes it possible to trace connections between the visible and the hidden, the dominant and the marginalised, ideas and institutions. It allows us to see how power works through language, literature, culture and the institutions which regulate our daily lives" (47).

Ashcroft, Griffiths, and Tiffin strongly support the parallelism between patriarchal and colonialist discourses. They state that "both patriarchy and imperialism can be seen to exert analogous forms of domination over those they render subordinate" (83). Furthermore, the ways in which both discourses claim objectivity, construct the subjectivity of both the dominant and subordinated groups, and employ language as a tool for domination and as a means of constructing identity, among other parallels, make the two discourses homologous in form (Ashcroft et al 102).

Edward Said states that it is "no paradox that Conrad was both imperialist and anti-imperialist" (xviii). In Culture and Imperialism, Said notes some of Conrad's strengths as an anti-imperialist writer. One such strength is the way in which Conrad's novella contextualizes and illustrates the contingencies, violence, and waste of colonialism (25-6). Another strength that Said identifies is the way in which Conrad "permits his later readers to imagine something other than an Africa carved up into dozens of European 
colonies, even if, for his own part, he had little notion of what that Africa might be" (26). Nevertheless, despite Conrad's liberal anti-imperialistic leanings, he is ultimately limited by his unconscious Eurocentrism. Said states of Nostromo that

[Conrad] writes as a man whose Western view of the non-Western world is so ingrained as to blind him to other histories, other cultures, other aspirations. All Conrad can see is a world totally dominated by the Atlantic west, in which every opposition to the West only onfirms the West's wicked power. What Conrad cannot see is an alternative to this cruel tautology. (xviii)

In this passage, Said identifies Conrad's Eurocentrism and, thus, his ability and his susceptibility to perpetuating colonialist discourse. Said notes further that "As a creature of his time, Conrad could not grant the natives their freedom, despite his severe critique of the imperialism that enslaved them" (30). Thus, Conrad's liberal anti-imperialism does not neutralize his Eurocentrism, nor does it void the imperialist/colonialist elements found within Heart of Darkness. Indeed, as Achebe notes, the kind of liberalism Conrad and his primary narrator, Marlow, espouse "almost always managed to sidestep the ultimate question of equality between white people and black people" (342-43). The sidestepping of this question in the world of the novella and, potentially, in the minds of its readers is a continuation of rhetorical and literal violence. Furthermore, Achebe notes that Conrad's representation of Africa "as setting and backdrop ... eliminates the African as human factor. Africa as a metaphysical battlefield devoid of all recognizable humanity" (343-44). Despite its anti-imperialist strengths, then, Heart of Darkness has the potential to continue to dehumanize and depersonalize "a section of mankind [that] has suffered untold agonies and atrocities in the past and continues to do so in many ways and in many places today" (Achebe 346). With these things in mind, the representations of black Africans in Heart of Darkness must be read with methodological resistance.

Colonialist discourse is driven by notions of alterity, which are evinced through the frequent construction of the purported European/non-European binary in alignment with others such as clean/dirty, Christian/heathen, human/animal, and so on. Indeed, by situating nonEuropean colonized peoples as dichotomous to the European colonizers, Europe's colonial project can be justified as a mission of emancipation, education, and spiritual salvation. For instance, the mind/body binary objectifies colonized peoples by constructing them solely as bodies; doing so enables Europe's imperial tutelage and imperative to use, enslave, and exploit colonized peoples.

Heart of Darkness primarily figures the Congolese in relation to their bodies and physicality. One of the primary representations of black Africans in the novella is the characterization of the Congolese as embodiments of the wilderness. The first recognition of this embodiment is the ways in which the Congolese wilds are personified throughout the novel: "a treacherous appeal to the lurking death, to the hidden evil, to the profound darkness of its heart" (33), "and the whole lot [of sandbars were] seen just under the water exactly as a man's backbone" (43), and "the face of the forest was gloomy" (44; emphases added). In these descriptions, the wilderness is collocated with words such as mystery and death, despair and gloom, locating it as not only the enemy, but also as a site of death for anyone who enters it. Those who embody it, on the other hand, are considered "Dead in the centre" (10) - living dead and, of course, not fully human.

If the wilderness is given physical features, it is also given the capacity for (human) sound: "The bush began to howl" (45) and "The tumult of angry and warlike yells was checked instantly and then from the depths of the woods went out such a tremulous and prolonged wail of mournful fear and utter despair" (46; emphases added). As these passages help illustrate, the majority of the Congolese's communication within the novella is represented as screaming or wailing, i.e. pre-verbal, save two instances of Conrad's bestowal of English upon the Congolese.

Finally, the black African characters are seen as physical embodiments of the wilderness itself: "Suddenly round the corner of the house a group of men appeared, as though they had come up from the ground," and further, "I noticed that the crowd of savages was vanishing ... as if the forest that had ejected these beings so suddenly had drawn them in again as the breath is drawn in a long aspiration" (59; emphases added). In these passages, the Congolese are characterized as the foot-soldiers of the larger threat to Europeans - the wilderness. This representation is ironic considering that the major, obscured threat in the novella is to the Congolese and their way of life by means of imperialism and colonialism, of which Europeans in Africa are the infantry. Figuring the Congolese as embodiments of the wilderness-and, thus, of darkness, mystery, and death-is an example of colonialist discourse in the novel that requires resistance if we are to read ethically.

Another way in which black Africans and black African bodies get figured in the novel is in animalistic, bestial terms; this construction is in alignment with the humananimal binary posited by European imperialism and colonialism. As mentioned previously, situating the colonized in this way enables the furthering of Europe's colonial project. The Congolese are often described in relation to their movements, which are characterized as frenzied and irrational. Often, the black African characters are found stamping their feet. While at the First Company station in the Congo, Marlow reports that "Suddenly there was a growing murmur of voices and a great tramping of feet" (19); when trekking into the interior with a full train of 
African bearers, Marlow remarks, "Day after day ... the stamp and shuffle of sixty pair of bare feet behind me" (20; emphases added). As well, the Congolese are periodically described as crawling: "While I stood horror-struck one of these creatures rose to his hands and knees and went off on all-fours towards the river to drink" (17) and "If it had come to crawling before Mr. Kurtz, [the Russian] crawled as much as the veriest savage of them all" (58; emphases added).

The suggestion that black Africans are bestial creatures is furthered by the language used to describe their physical characteristics: "All their meagre breasts panted together, the violently dilated nostrils quivered, the eyes stared stonily uphill" (16). In this passage, the various body parts of the Congolese are scarcely able to conceal their frenzied, aggressive proclivities. Throughout the novella, the whites of their eyeballs, the gleam of their eyes, their sharp teeth, and the blank expressions on their faces are the dominant means of representing black Africans. The Congolese are also often described as animalistic through figurative terms. In speaking of the Congolese boiler-man and helmsman, respectively, who were accompanying him down the river, Marlow states that "He was there below me and, upon my word, to look at him was as edifying as seeing $a$ dog in a parody of breeches and a feather hat walking on his hind legs. A few months of training had done for that really fine chap" (36), and "That fool-helmsman ... was lifting his knees high, stamping his feet, champing his mouth, like a reined-in horse" (45i emphases added). In these passages, black Africans are not figured as simply any animals but as ones over which Europeans have control, and which they have domesticated. Thus, as long as the European has this control over the black African-"He was there below me"that African is able to move, in the same passage, from being a "savage" to a "really fine chap" $(36$; emphasis added).

In addition to being described as like domesticated animals, the Congolese are figured as carnivorous and, inevitably, aggressive animals: "I would just as soon have expected restraint from a hyena prowling amongst the corpses of a battlefield" (42). Indeed, in line with this representation, the Congolese are often described as being violent cannibals, an additional colonial naming and a further diminution of their humanity. In figuring them as animalistic and bestial, the novella's representations of black Africans are further aligned with colonialist discourse and, thus, the continued dehumanization of black Africans.

Achebe states that descriptions of black Africans who are "not just limbs or rolling eyes" are "rare" in Heart of Darkness (340). Indeed, when the Congolese are not figured as embodiments of the wilderness or as violent animals, they are rarely figured as whole beings at all. In fact, they are never figured as fully human in the same sense that Europeans are figured as human: "They were big powerful men with not much capacity to weigh consequences, with courage, with strength, even yet, though their skins were no longer glossy and their muscles no longer hard" (41). This passage emphasizes the colonial construction of the colonized as all body and no mind. As well, this passage reveals a sense of disappointment at the fact that the Congolese can no longer be admired, no matter how condescendingly, for their sheer physicality. This is telling because, throughout the work, physicality is all that the Congolese (are allowed to) have. However, even that admirable possession is tenuous.

In further support of Achebe's earlier observation, one encounters descriptions of black Africans in terms of mere shapes, outlines, or parts more often than one encounters a full human being: "[T]hey were nothing earthly now, nothing but black shadows of disease and starvation lying confusedly in the greenish gloom" (17). As this passage makes clear, the Congolese are not granted full humanity, only a suggestion of humanity. Conrad often describes the Congolese as shapes darting at the edge of the forest or the river: "I made out deep in the tangled gloom, naked breasts, arms, legs, glaring eyes-the bush was swarming with human limbs in movement, glistening of bronze colour" (45) and "Dark human shapes could be made out in the distance, flitting indistinctly against the gloomy border of the forest" (60). In each instance, black Africans are described as "incomplete, evanescent" (45), and the mess of their seemingly unconnected limbs limits the ability to see them as full human beings.

A further colonial construction of black African identity and bodies can be seen in relation to how often the Congolese appear en masse. For instance, when Marlow sees a group of Congolese on the river bank, he remarks that "the crowd ... flowed out of the woods again, filled the clearing, covered the slope with a mass of naked, breathing, quivering, bronze bodies" (66). In this way, the Congolese characters are further isolated from being seen as individuals with human agency and, indeed, identity. The figuring of black Africans as bodies throughout Heart of Darkness, whether in relation to the wilderness, to bestiality, or to sheer physicality, keeps black African identities firmly situated within colonialist discourse and, therefore, in a dehumanized state.

A practice of resistant reading is essential for an ethical reading of Joseph Conrad's Heart of Darkness and its representations of black Africans. Although the novella contains many elements that can be viewed as antiimperialist, such elements do not offset the dehumanizing elements of its colonialist discourse. Throughout the work, the Congolese are figured primarily in terms of their bodies. By constructing black African bodies and, therefore, identities as embodiments of the deadly African wilderness, Europe produces its own permission to wage a rhetorical and literal war with the wilderness and its alleged infantry. 
Constructions of black Africans as animalistic and bestial abound throughout the novella, a further alignment with colonialist discourse. Everything about the Congolese, from their movements to their eyeballs, is described as fierce and frenzied, descriptions that verge on the appallingly hyperbolic. Furthermore, when not described as embodying the wilderness or in animalistic terms, the Congolese are rarely described as full bodies and full human beings. Instead, the Congolese are often described as indistinct shapes and shadows or as a mess of fleeting body parts, as if to suggest their "vanishing" status under colonial rule. Taken together, these constructions form a dehumanizing, colonialist matrix that has literal and rhetorical consequences. As a result, employing a practice of resistant reading to these elements has rhetorical and literal consequences as well. Rhetorically, black Africans are allowed to begin the quest for true self-knowledge because, as Rich states, "Until we can understand the assumptions in which we are drenched we cannot know ourselves" ("Awaken" 18). As well, this practice discourages the perpetuation of colonialist discourse by both Africans and non-Africans. Speaking literally, black Africans are allowed to begin the process of claiming and acting versus receiving and being acted upon, a difference that Rich notes "can ... mean the difference between life and death" ("Claiming" 608). Indeed, as colonialism and colonial enslavement were discursive and embodied realities, their resistance must also be discursive and embodied. Reading literature and the way in which one reads it, then, are not only political events, but also political choices: the choice between the rhetorical and literal death of a sector of society or its rhetorical and literal life. Indeed, it is the ultimate choice.

\section{Acknowledgements}

My warmest thanks to Dr. Susan Gingell for her attentive and passionate teaching of "Literature and Colonialism" in the Winter of 2013, the birthplace of not a few revelations, including this paper. My gratitude also extends to Dr. Nancy Van Styvendale for her mentorship throughout this process and to Dr. Douglas Thorpe for his encouragement as I was editing.

\section{Works Cited}

Achebe, Chinua. "An Image of Africa: Racism in Conrad's Heart of Darkness." Joseph Conrad's Heart of Darkness: A Norton Critical Edition. Ed. Paul B. Armstrong. New York: Norton, 2006. 336-49. Print.

Ashcroft, Bill, Gareth Griffiths and Helen Tiffin. PostColonial Studies: The Key Concepts. London: Routledge, 2000. Web.
Conrad, Joseph. "Heart of Darkness." Joseph Conrad's Heart of Darkness: A Norton Critical Edition. Ed. Paul B. Armstrong. New York: Norton, 2006. 17-98. Print.

Fetterley, Judith. The Resisting Reader: A Feminist Approach to American Fiction. Bloomington, Indiana: Indiana University Press, 1978. Print.

Loomba, Ania. Colonialism/Postcolonialism. London: Routledge, 1998. 44-47. Web.

Rich, Adrienne. "When We Dead Awaken: Writing as ReVision." College English 34.1 (1972): 18-30. Web.

---. "Claiming an Education." (1977): 608-611. Web. $<$ http://www.yorku.ca/cvandaal/files/ClaimingAnEdu cation.pdf>

Said, Edward. Culture and Imperialism. New York: Vintage, 1993. Print. 